\title{
Combined Use of Electrical Resistivity Tomography and Hydrochemical Data to Assess Anthropogenic Impacts on Water Quality of a Karstic Region: A Case Study from Querença-Silves, South Portugal
}

\author{
Teresa E. Leitão • Rogério Mota • Maria Emília Novo • \\ João Paulo Lobo-Ferreira
}

Received: 7 November 2013 / Accepted: 13 December 2013 /Published online: 24 April 2014

(C) Springer International Publishing Switzerland 2014

\begin{abstract}
The presence of highly vulnerable karstic systems in areas of intense human activities often results in the degradation of existing surface- and groundwater quality status. Water quality protection and improvement, as required by the Water Framework Directive (WFD), depends on correct identification and prioritisation of the most relevant pollution sources within complex multi-stressor conditions. This paper presents a methodology that combines the use of hydrogeology, water quality and quantity data, and electrical resistivity tomography methods to access different anthropogenic impacts upon the water cycle, focusing on the water quality of a section of the Portuguese karstic Querença-Silves aquifer. During this study an interpretation of the possible interconnections between pollutant sources, their pathways and local surface-groundwater connections was made, based on data obtained from field campaigns. As a result of this study, the areas with more interconnection between surfaceand groundwater were identified, namely the influent sites from the local stream into the aquifer. The impact of the diffuse pollution sources was verified at the monitoring points, especially those located downstream of large farming plots. Pollution in this karst aquifer results from seepage through agricultural areas and infiltration at the influent points of the stream. This aspect of stream influence upon the aquifer means that pollution sources located upstream of the area of the aquifer (e.g., a WWTPWastewater Treatment Plant) can also contribute to the aquifer pollution.
\end{abstract}

T. E. Leitão $(\bowtie) \cdot$ R. Mota $・$ M. E. Novo $\cdot$ J. P. Lobo-Ferreira

National Laboratory for Civil Engineering (LNEC), Av. do Brasil 101, 1700-066 Lisbon, Portugal e-mail: tleitao@lnec.pt

R. Mota

e-mail: rmota@lnec.pt

M. E. Novo

e-mail: enovo@lnec.pt

J. P. Lobo-Ferreira

e-mail: lferreira@lnec.pt 
Keywords Water quality $\cdot$ Impacts $\cdot$ Human activities $\cdot$ Geophysical methods and water information

\section{Introduction}

In contrast to sedimentary terrains where groundwater occurs in the pores of horizontal rocks, like sandstone or in the interstitial spaces of deposits, in hard-rock terrains groundwater occurs in fractures, fissures, crushed zones and joints. In karstic formations, like those present in the Ribeiro Meirinho case study, which is the focus of this work, water pathways carved within the rock formation play an important role in groundwater circulation.

The use of non-intrusive geophysical methods, e.g., electrical resistivity tomography, is a common approach to complement discrete water quantity and quality field data and information (e.g., Gemail et al. 2011; Sainato et al. 2012). These methods are, however, less commonly applied to karstic areas. Electrical resistivity measurements are a function of the type of soil or rock, its porosity, and the conductivity of the fluids that fill the pore spaces. Electrical resistivity values are inversely correlated to electrical conductivity. In a resistivity survey, a direct current of intensity is passed into the ground through a pair of current electrodes and the resulting potential drop $\Delta \mathrm{V}$ is measured across a pair of potential electrodes. Therefore, more saturated geological formations, containing high water content and more dissolved salts or pollutants, will lead to lower electrical resistivity profiles due to the ease at which electrical current crosses the high electrical conductivity media. Also, the determination of the water table position by the resistivity method is based on the fact that the saturated materials will have lower resistivity than the unsaturated materials.

With geophysical surveys, one can identify the most saturated areas (lower resistivity spots) and assess the subsurface areas more favourable to aquifer recharge and, simultaneously, which need protection in order to guarantee groundwater quality.

In this study, the impact that different stressors have on the quality of water was assessed based on the knowledge gathered from previous works in the region (Monteiro et al. 2006; Reis et al. 2007) and several water monitoring campaigns, complemented by geophysical profiles. The areas downstream of the main pollution sources were monitored both for surface and groundwater. The negative influence of surface water quality in locations where the Ribeiro Meirinho stream can contribute to the aquifer recharge was confirmed with the geophysical survey.

\section{Site Description}

\subsection{Location and Characteristics}

The Ribeiro Meirinho case study area is located northeast of Silves, Algarve region, Portugal (Fig. 1). The hydrogeological setting is the Querença-Silves karstic aquifer, with a complex compartmented structure, with two distinct domains: a western domain and an eastern domain. Its western domain has a well-developed karst, westward flow direction, with the main discharge areas along the Arade river, with particular relevance to Estômbar springs (westmost point). Its eastern domain has 
more random flow directions, less regular piezometric surfaces (Fig. 1) and a lower karst development. The tectonic activity of this region results in its widespread fracturing, defining a significant number of semi-independent aquifer blocks, with more or less constrained and restricted hydraulic links between them. Such hydraulic restrictions are more expressive in the eastern domain, because in the western domain the pervasive karstic network largely obliterates such tectonic setting (Mendonça and Almeida 2003; Monteiro et al. 2006).

The Ribeiro Meirinho stream is located in the central-western area of QuerençaSilves aquifer and its upper reaches are located outside the aquifer, in Serra Algarvia. The latter are Palaeozoic terrains, composed mainly of schist and gray wakes, essentially impervious lithologies, being therefore, the main source of water for this stream until it reaches the Jurassic limestones, dolomites, dolomitic limestones and other, less important, calcareous formations composing the karst aquifer of Querença-Silves.

Water availability in the region is low, and therefore, the importance of its preservation is clear. According to Costa et al. (1985), the average annual rainfall of the area where the Querença-Silves Aquifer System is located ranges from about $550 \mathrm{~mm} /$ year at the southwestern tip of the aquifer system, increasing to $\mathrm{E}$ and $\mathrm{NE}$, with $800 \mathrm{~mm} /$ year of rainfall at its SE boundary, and above $800 \mathrm{~mm} / \mathrm{year}$ across the remaining eastern sector. There is evidence of a drought recurrence trend of 10 years for the most intense droughts. The average annual recharge of Querença-Silves aquifer, for the period 1941-1991, was estimated as $314 \mathrm{~mm} / \mathrm{year}$, i.e., $100 \times$ $10^{6} \mathrm{~m}^{3} /$ year (Oliveira et al. 2008). For the period 1979-2009, an average annual recharge value of $294 \mathrm{~mm} /$ year was estimated (Oliveira 2011), equivalent to $94 \times$ $10^{6} \mathrm{~m}^{3} /$ year.

Due to its karstic properties, there is a strong relationship between the aquifer and the streams with some influent sections that can significantly contribute to its recharge (Monteiro et al. 2006; Reis et al. 2007). This is the case of Ribeiro Meirinho, which undergoes a sharp reduction of the flow rate when it reaches the calcareous formations, having several sinks in its bed. It is estimated that besides direct recharge, an extra amount of $62 \times 10^{6} \mathrm{~m}^{3} /$ year, originating from surface flow produced in the drainage area outside the aquifer, infiltrates when the rivers reach the aquifer system (Oliveira and Oliveira 2012).

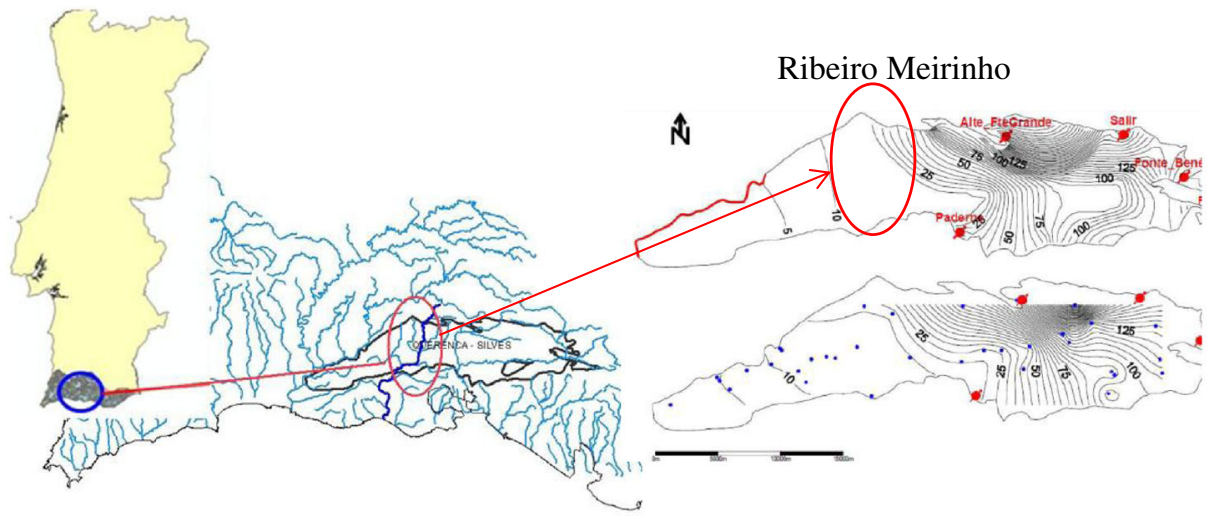

Fig. 1 Site location along Ribeiro Meirinho stream and central-western area of Querença-Silves aquifer and its piezometry (upper right: modelled; lower right: measured) 


\subsection{Main Stressors}

The study area is located in a rural region and the main water quality stressors are related to agricultural activity. The other existing pollution sources are a wastewater treatment plant (WWTP), septic tanks and livestock production units. The agriculture pattern is dominated by citrus orchards, with a very marginal component of market gardens and vineyards (Fig. 2.).

Table 1 presents the estimated concentration of nitrogen $(\mathrm{N})$ and phosphorus $(\mathrm{P})$ in the effluent, contributed either directly into the soil or into water bodies, by each type of activity.

Figure 3 shows the loads (volume multiplied by concentration) of nitrogen (cf. Table 1) coming from the different pressures existing in the area, shown as a percentage. This shows clearly the strong influence of agriculture, especially citrus orchards.

Data obtained from INSAAR (National Inventory of Water Supply and Waste, Inventário Nacional de Sistemas de Abastecimento de Água e de Águas Residuais in Portuguese) show that the WWTP outflow is directly disposed into Ribeiro Meirinho after a secondary treatment, with an average flow rate between 0.262 and $0.320 \times 10^{6} \mathrm{~m}^{3} /$ year. Hence, a $100 \%$ of the effluent pollutants from the WWTP are considered to enter this surface water body. The following water quality parameters are measured on a monthly basis: $\mathrm{pH}, \mathrm{BOD}_{5}\left(\mathrm{mgO}_{2} / \mathrm{L}\right)$, $\mathrm{COD}\left(\mathrm{mgO}_{2} / \mathrm{L}\right), \mathrm{P}$ total $(\mathrm{mgP} / \mathrm{L}), \mathrm{N}$ total $(\mathrm{mgN} / \mathrm{L})$, Nitrates $\left(\mathrm{mgNO}_{3} / \mathrm{L}\right), \mathrm{TSS}(\mathrm{mg} / \mathrm{l}), \mathrm{Cl}$ $(\mathrm{mgCl} / \mathrm{L})$, and Coli $(\mathrm{ufc} / 100 \mathrm{~mL})$. Figure 4 shows the results of nitrates and coliform concentrations in WWTP and in Ribeiro Meirinho surface water stream. The annual average concentration of nitrates varies from 117 to $197 \mathrm{mgNO}_{3}{ }^{-} / \mathrm{L}$.

For the farming areas, the effluent pollutant concentrations were calculated considering the amount of fertilizers traditionally used in the area for each specific culture, and assuming that $70 \%$ is being subtracted by the plant requirements and $30 \%$ are lost to soil due to excessive fertilization (e.g., Isherwood 2000).

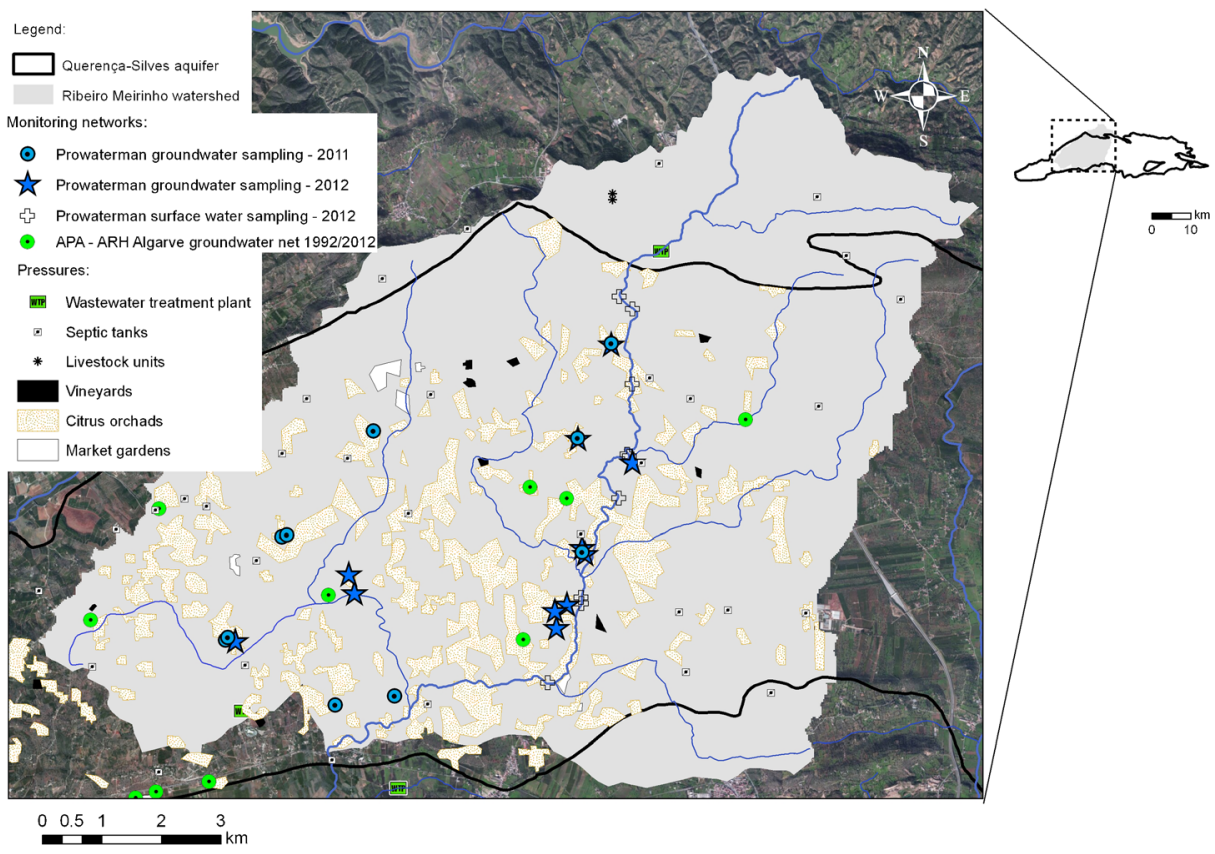

Fig. 2 Land use, main pressures and monitoring networks 
Table 1 Pollutant rejections by type of activity

\begin{tabular}{|c|c|c|c|c|c|c|c|}
\hline \multirow{5}{*}{$\begin{array}{l}\text { Origin } \\
\text { WWTP }\end{array}$} & \multicolumn{2}{|c|}{$\begin{array}{l}\text { Flow rate }\left(\mathrm{m}^{3} / \mathrm{y}\right) \\
\text { or application } \\
\text { area (ha) }\end{array}$} & \multicolumn{2}{|c|}{$\begin{array}{l}\text { Rejected pollutant } \\
\text { concentrations }\end{array}$} & \multirow{3}{*}{$\begin{array}{l}\% \text { of rejection lost } \\
\text { into soil/water } \\
100 \%\end{array}$} & \multicolumn{2}{|c|}{ Loads (ton/y) } \\
\hline & $0.262^{(a)}$ & $\times 10^{6} \mathrm{~m}^{3} / \mathrm{y}$ & $157^{(\mathrm{b})}$ & $\mathrm{mgNO}_{3}{ }^{-} / \mathrm{L}$ & & 9.31 & $\mathrm{~N}$ \\
\hline & to & & & & & 11.37 & \\
\hline & $0.32^{(a)}$ & & $5.5^{(b)}$ & $\mathrm{mgP} / \mathrm{L}$ & & 1.44 & $\mathrm{P}$ \\
\hline & & & & & & 1.76 & \\
\hline \multicolumn{8}{|l|}{ Agriculture } \\
\hline \multirow[t]{2}{*}{ Citrus orchards } & $1,358.530$ & ha & 160 & $\mathrm{kgN} / \mathrm{ha} / \mathrm{y}$ & $30 \%$ & 65.21 & $\mathrm{~N}$ \\
\hline & & & 80 & $\mathrm{kgP} / \mathrm{ha} / \mathrm{y}$ & & 32.60 & $\mathrm{P}$ \\
\hline \multirow[t]{2}{*}{ Vineyards } & 15.830 & & 20 & $\mathrm{kgN} / \mathrm{ha} / \mathrm{y}$ & & 0.095 & $\mathrm{~N}$ \\
\hline & & & 13.5 & $\mathrm{kgP} / \mathrm{ha} / \mathrm{y}$ & & 0.064 & $\mathrm{P}$ \\
\hline \multirow[t]{2}{*}{ Market gardens } & 30.570 & & 48 & $\mathrm{kgN} / \mathrm{ha} / \mathrm{y}$ & & 0.44 & $\mathrm{~N}$ \\
\hline & & & 21.6 & $\mathrm{kgP} / \mathrm{ha} / \mathrm{y}$ & & 0.20 & $\mathrm{P}$ \\
\hline \multirow[t]{2}{*}{ Septic tanks } & Point source & & 5783.5 & $\mathrm{kgN} / \mathrm{y}$ & $20 \%$ & 1.16 & $\mathrm{~N}$ \\
\hline & & & 1499.8 & $\mathrm{kgP} / \mathrm{y}$ & & 0.30 & $\mathrm{P}$ \\
\hline \multirow[t]{2}{*}{ Livestock production } & Point source & & 1594.2 & $\mathrm{kgN} / \mathrm{y}$ & $100 \%$ & 1.59 & $\mathrm{~N}$ \\
\hline & & & 531.4 & $\mathrm{kgP} / \mathrm{y}$ & & 0.53 & $\mathrm{P}$ \\
\hline
\end{tabular}

(a) INSAAR data http://www.google.pt/url?sa=t\&rct=j\&q=\&esrc=s\&source=web\&cd=7\&ved= 0CGQQFjAG\&url=http $\% 3 \mathrm{~A} \% 2 \mathrm{~F} \% 2 \mathrm{Finsaar}$.inag.pt $\% 2 \mathrm{Fbo} \% 2 \mathrm{Fcontents} \% 2 \mathrm{Fresultadostabelasdados} \%$ 2 F 12681367577896 .x 1 s \& e i=p w r T U K e G Y X X Q e s v Y G A B g \& s g = AFQjCNFTwsRf1bC1PHLXOQtdvoe5IvyxUQ\&bvm=bv.1355534169,d.ZG

(b) Data from: http://www.aguasdoalgarve.pt/qualidadeefluente.php

For the septic tanks, the pollution load of $\mathrm{N}$ and $\mathrm{P}$ per unit was calculated by evaluating the average population in each human settlement (village) connected to such structures, multiplied by the pollution load by person-equivalent. Due to the differences in population density, average population by village will be different from one county to another, and this was accounted for in the calculations made by the authors. The pollutant removal capacity of the septic tanks was also considered, assuming that they are running in perfect conditions, therefore, having a removal capacity of $80 \%$ of the pollution load produced. The remaining

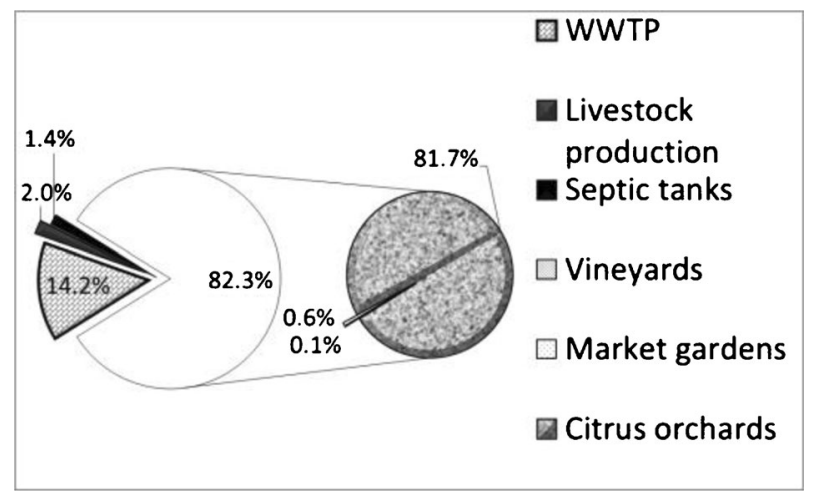

Fig. 3 Nitrogen loads originating from the different pressures in the study area 


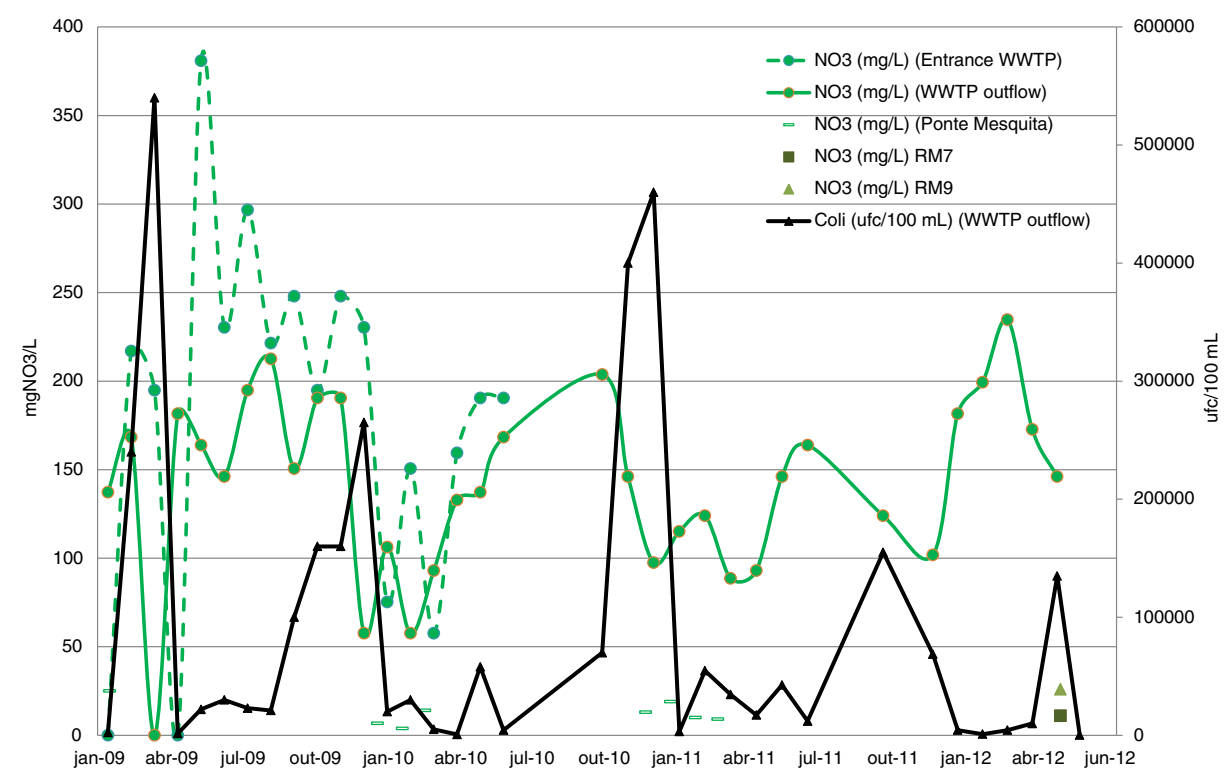

Fig. 4 Concentration in nitrates and coliforms in the WWTP and in the surface water stream (Ribeiro Meirinho)

$20 \%$ should be lost to the soil, but this figure can be higher, depending on the efficiency of the septic tank.

Livestock production units are pig production for meat, and are located outside the aquifer, in the upper reaches of Ribeiro Meirinho. It was considered that $100 \%$ of its discharge enters Ribeiro Meirinho, since the soil outside the area is impervious until it reaches the aquifer terrains, where part of its flow is assumed to infiltrate. The livestock pollution loads/unit was calculated as the average of the total value considered to be point source discharged by the livestock units in the study area. The data were gathered from the recent watershed planning reports (Nemus, Ecossistema and Agro.ges 2011).

Having in mind the annual recharge value (Oliveira and Oliveira 2012) and the annual loads calculated, we can estimate that the recharge of water in the cultivated areas has an average concentration of $28.65 \mathrm{mgNO}_{3}{ }^{-} / \mathrm{L}$, which corresponds to $65.7 \mathrm{t} \mathrm{N}$ (sum of agriculture in Table 1) converted to $\mathrm{NO}_{3}{ }^{-}$and divided by $19.25 \times 10^{6} \mathrm{~m}^{3}$ annual recharge value in the areas with cultivated outcrops.

\section{Materials and Methods}

\subsection{Water Quality Monitoring}

Based on the two main pressures in the watershed (Fig. 2), a general assessment of the water quality was initially made, followed by a focus on a specific area where some sections of the stream bed are recharging the aquifer. Water quality was monitored for both surface- and groundwater. The first campaign was carried out in May 2011 (Fig. 2) and aimed at a global characterization of water status, identifying 
areas with poorer status. The following chemical parameters were analysed: $\mathrm{Na}^{+}$, $\mathrm{Ca}^{2+}, \mathrm{K}^{+}, \mathrm{Mg}^{2+}, \mathrm{Cl}^{-}, \mathrm{HCO}_{3}{ }^{-}, \mathrm{SO}_{4}{ }^{2-}, \mathrm{NO}_{3}{ }^{-}, \mathrm{NH}_{4}{ }^{+}, \mathrm{NO}_{2}{ }^{-}, \mathrm{PO}_{4}{ }^{3-}, \mathrm{Al}, \mathrm{As}, \mathrm{Be}, \mathrm{Ba}$, $\mathrm{Cd}, \mathrm{Cr}, \mathrm{Zn}, \mathrm{Cu}, \mathrm{Fe}, \mathrm{S}, \mathrm{Cu}, \mathrm{Pb}, \mathrm{Zn}$, organic matter, total hydrocarbons, detergents, and total coliforms. As a result of the data obtained, the case study area was focused on Ribeiro Meirinho stream and the surrounding groundwater, during the second monitoring period carried out in May 2012. In all campaigns, representative samples were taken after the stabilization of electrical conductivity and $\mathrm{pH}$, or after a significant volume of water withdrawal.

The local water authority (APA-ARH Algarve) has also carried out a monitoring program since 1992, with historical information.

\subsection{Geophysical Surveys}

The resistivity method is one of the most suitable ones for groundwater studies (e.g., Carriere et al. 2013). Its basic principles are based on the fact that the electricity applied to the soil is conducted electrolytically through the interstitial fluid, so it is controlled mostly by porosity, water content, water quality, and dissolved salts, and then also by the resistivity of the rock matrix (Yazicigil and Sendlein 1982; Nielsen 1991; Meju 2002). The resistivity is given by

$$
\rho=K \frac{\Delta V}{I}
$$

where $\mathrm{K}$ is a geometric factor depending upon the relative position of the four electrodes (electrodes array).

Modern geophysical equipment, such as the ABEM S4000 resistivimeter with a multielectrode cable system used in the present survey, are characterised by automatic switching electrodes equally spaced along the profiles. This allows a quick collection of large data sets, enabling the execution of 2D electrical resistivity tomographies (ERT). The collected apparent resistivity data were inverted with RES2DINV algorithm (Loke 2002; Loke and Barker 1996), with incorporation of topographic effects.

Three sites to perform ERT were selected from the water campaigns results (Fig. 5). They intended to: (1) confirm the water electrical conductivity results, since higher electrical conductivity values will correspond to low resistivity, and (2) track the spots where surface- and groundwater have stronger interaction. Additionally, site selection naturally should take into account the local geological environment and the available space for the electrodes array.

The ERT were performed along six alignments using adipole-dipole array, as this array is the most adequate choice for geological environments with strong contrasts along the profile, a feature present in karst environments, and different dipole distances (dd), in order to have a higher investigation depth or to fit the spread to the available space. Table 2 presents the profile details.

All sites were chosen in places where surface water is expected to be influent into regional groundwater, and where water samples were taken for chemical analysis. Site A was located in a meander of Ribeiro Meirinho, with one of the profiles crossing it and the other along the stream. Site B was selected due to its location nearby water boreholes, and where the surface water in the stream decreases significantly, and Site C was selected as a possible recharge location due to previous knowledge. 

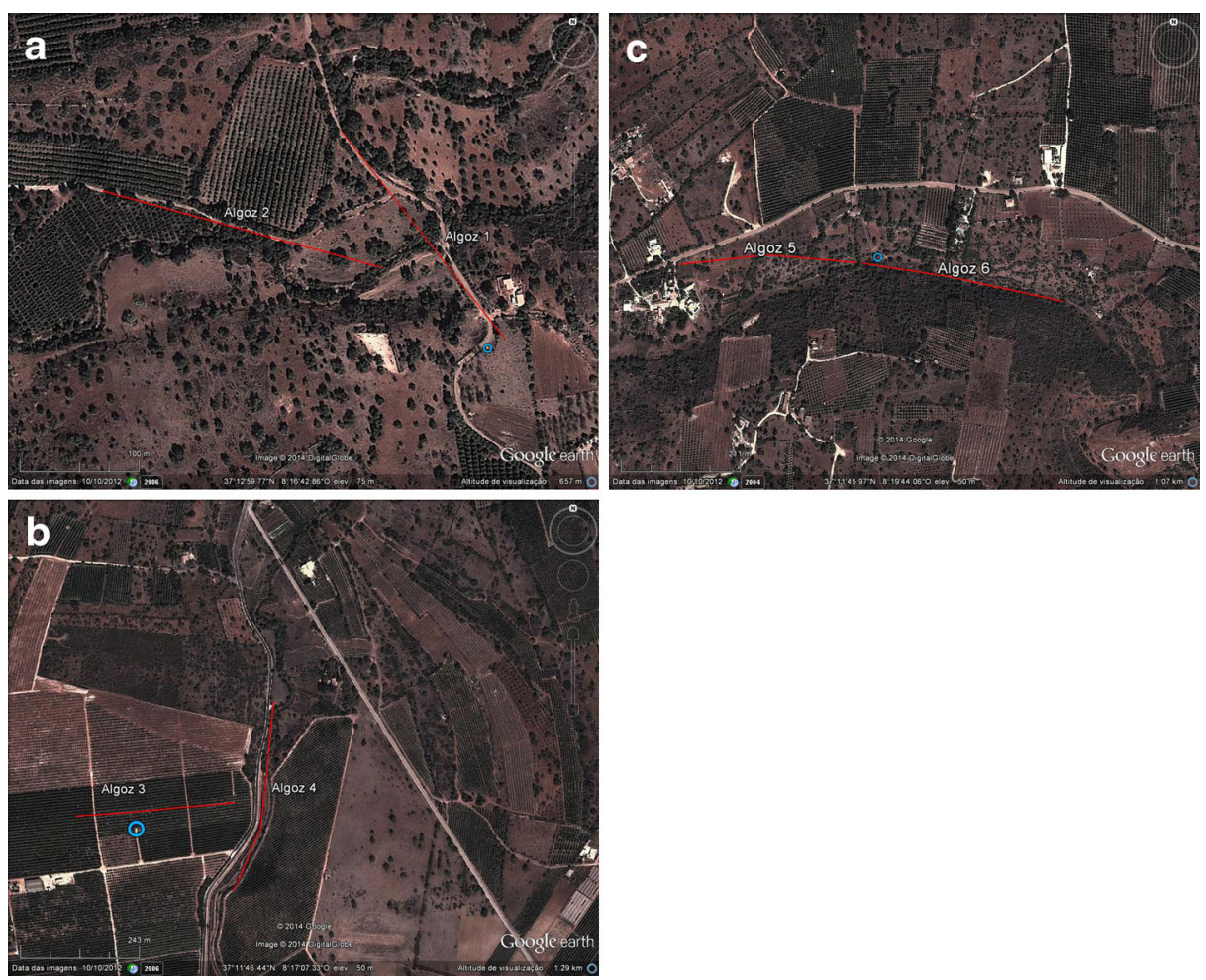

Fig. 5 Location of profiles (from Google earth): top left—Site A (Algoz1 and Algoz2); top right-Site B (Algoz3 and Algoz4); bottom left-Site C (Algoz5 and Algoz6). The white circle depicts the large wells at sites A and $\mathrm{C}$ and the water supply borehole at site $\mathrm{B}$

\section{Results}

\subsection{Water Quality}

Year 2011 results lead to the conclusion that groundwater has a bicarbonate calcic facies, typical of karstic areas. Only the groundwater from Alg13 (large well) seems to have a direct input from surface water, showing higher chloride content (Fig. 6). It was also possible to identify areas with strong influence from pollutant sources, recognized by concentrations of nitrates, phosphorus, boron, barium, and copper not present in background values for karstic areas (Fig. 6). These last three are probably

Table 2 Geophysical profile details

\begin{tabular}{llll}
\hline \multicolumn{2}{l}{ Identification } & Dipole distance $(\mathrm{m})$ & Total length (m) \\
\hline \multirow{2}{*}{ Site A } & Algoz 1 & 6 & 240 \\
& Algoz 2 & 6 & 240 \\
Site B & Algoz 3 & 10 & 390 \\
& Algoz 4 & 10 & 390 \\
Site C & Algoz 5 & 8 & 312 \\
& Algoz 6 & 10 & 390 \\
\hline
\end{tabular}



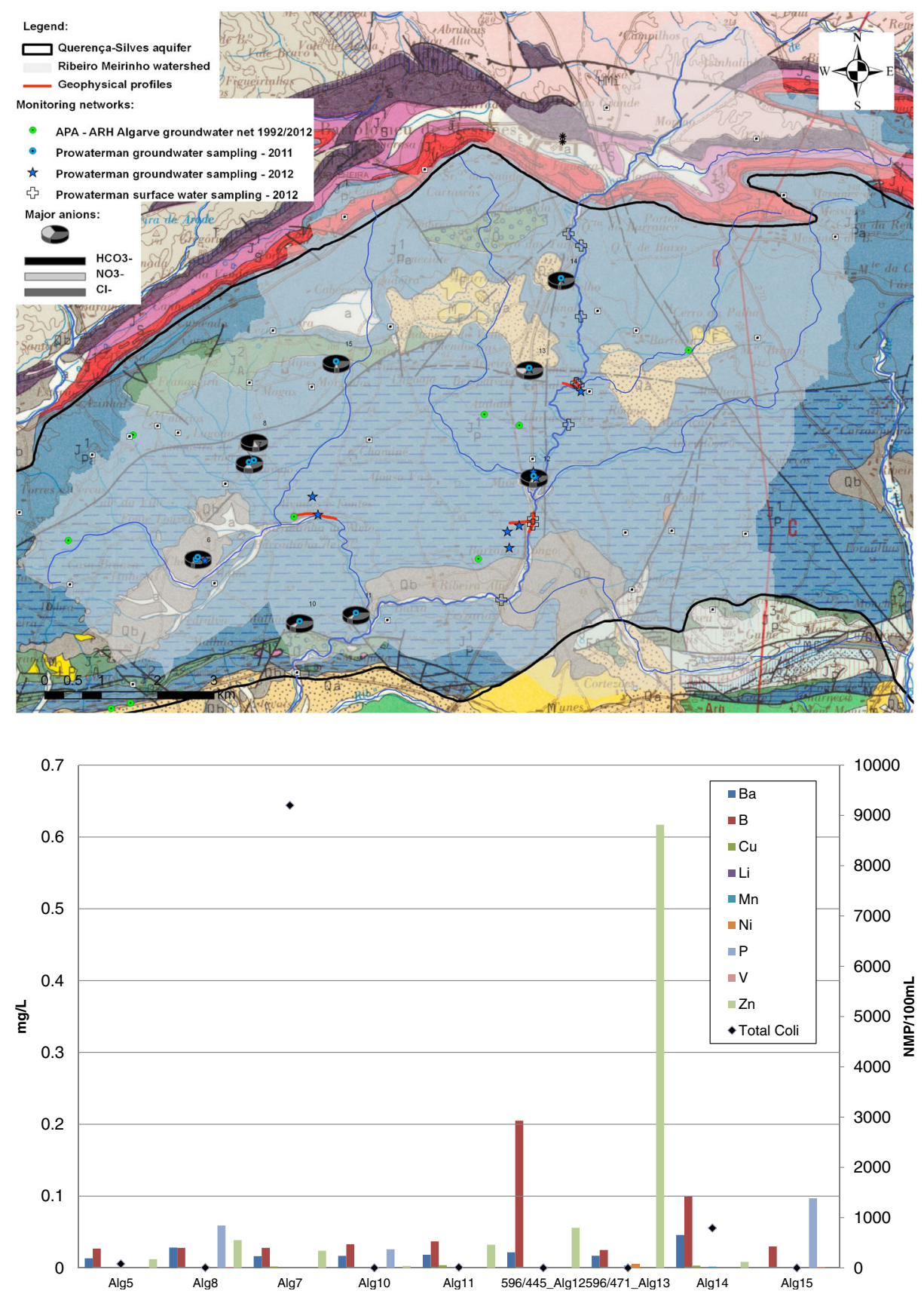

Fig. 6 Groundwater concentration (upper figure: major anions; lower figure: other elements)

related to the influence of the WWTP and livestock discharges directly made into Ribeiro Meirinho.

Based on the 2011 assessment of groundwater quality, another campaign was performed for surface- and groundwater, with data gathered specifically for electrical 
conductivity (Fig. 7) and nitrates (Fig. 8), as two representatives of the impact caused by the existing pressures.
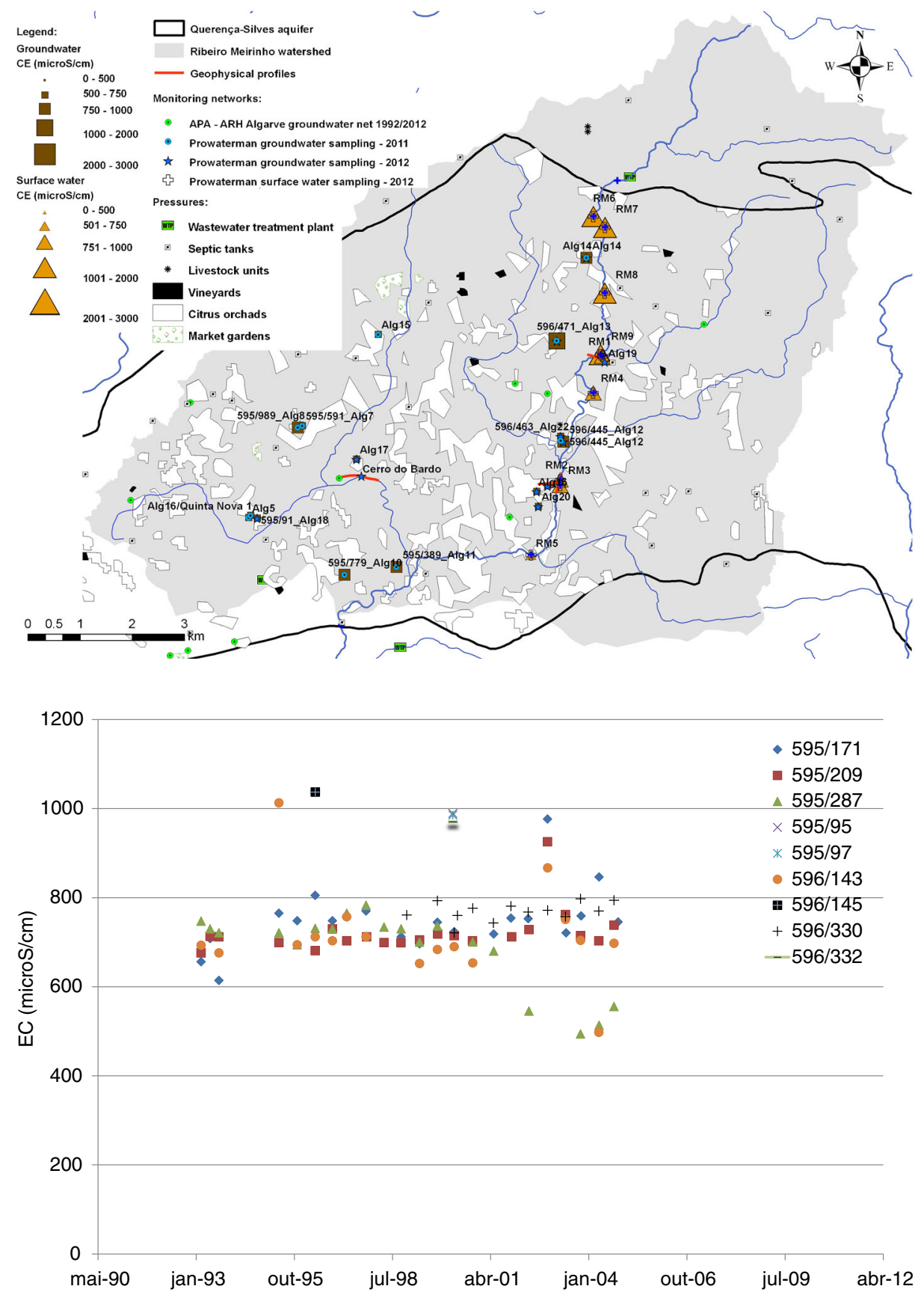

Fig. 7 Electrical conductivity values (upper figure: in surface- and groundwater; lower figure: evolution in groundwater) 
From Fig. 7, it is possible to see the negative influence of the WWTP on surface water quality, as well as some contribution into groundwater, in places near this stream where surface
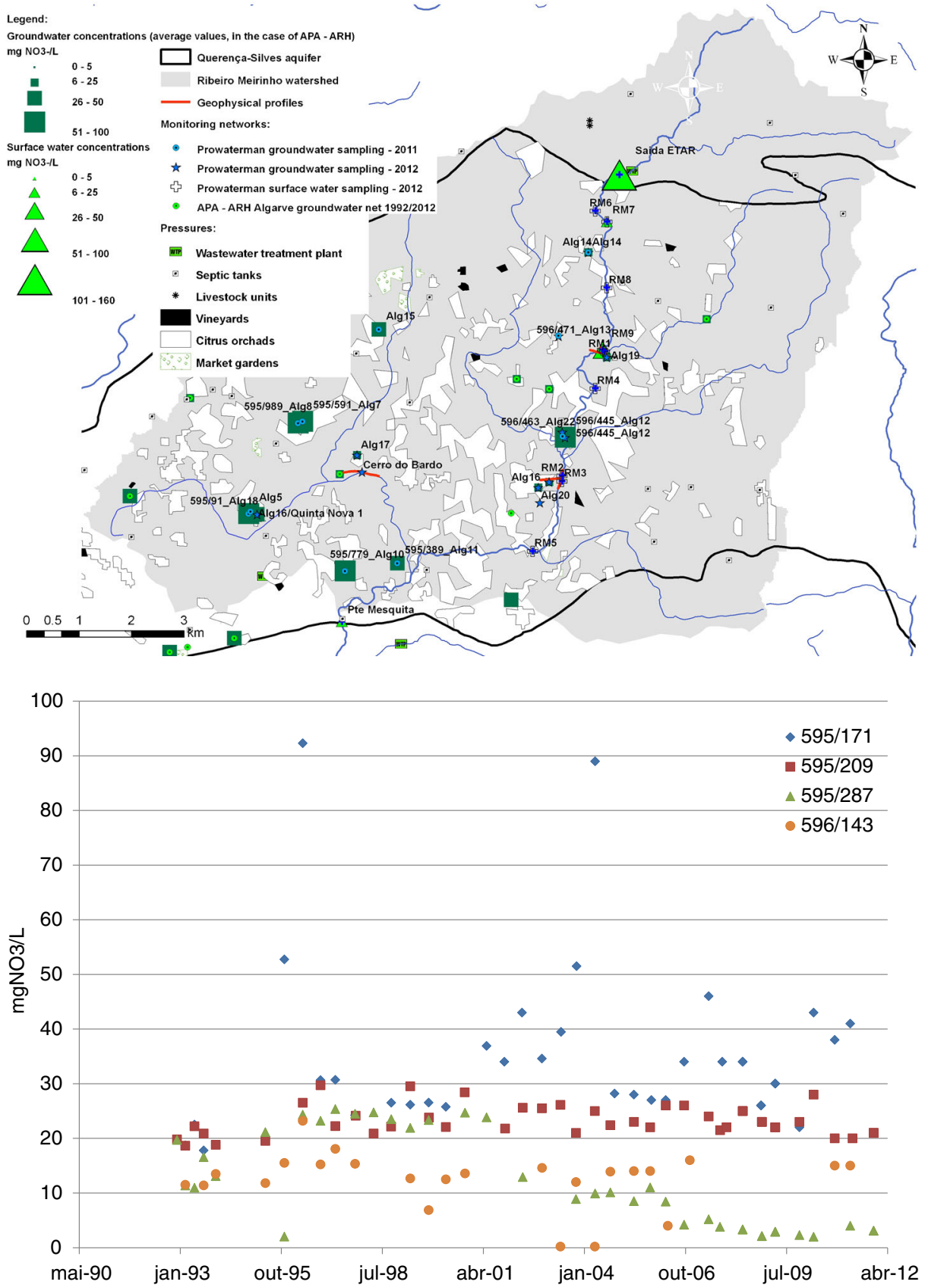

Fig. 8 Nitrate values (upper figure: in surface- and groundwater; lower figure: evolution in groundwater) 
water infiltrates to the aquifer. The EC values have been stable along the years, with a small upward trend and an increase of the variance.

For nitrate concentration in water, it is possible to see that the agricultural land use has a stronger impact than Ribeiro Meirinho (Fig. 8). In fact, as previously stated, agricultural practices contribute with loads around six times higher than those from the WWTP (Fig. 3). In the long term values, a seasonal effect (due to fertilization input) is clear in most wells, with higher standard deviation. This confirms the high recharge rates of this aquifer, which allow for the input of cleaner water in periods of low fertilization, decreasing the nitrates concentrations, but also the effect of irrigation charged with excess of nitrates (Fig. 8).

The water quality and the influence of surface water quality on regional groundwater quality is further analysed with the geophysical interpretation.

\subsection{Geophysics: Interpretation}

The geophysical data collected were of good quality, which is expressed in the inverted sections by a low RMS error (cf. in the upper left text of each profile) - although dipole-dipole is a high RMS error array. Coordinates on the horizontal axis of each resistivity model are distances from the beginning of the profile, always considering observer's vision in the south-north direction. The resistivity range is $35-6,336 \Omega$.m for all sites, with lower values in white.

At Site A, ERT profiles were performed on a meander of Ribeiro Meirinho and its influence in depth is clearly identifiable by the low resistivity zones in Algoz1 $(0-160 \mathrm{~m})$ and Algoz2 (100-240 m) (Figs. 5 and 9). The resistivity values also denote the high electrical conductivity of both surface- and groundwater, confirming the water quality data (Fig. 7). This points out that this place requires some attention concerning aquifer protection, since there is a clear capacity for surface water infiltration into the aquifer. The low resistivity values present in the top of Algoz1 (60-108 m) are due to the clayey texture of the top soil, which showed a high degree of saturation at the time of the survey. The very low resistivity $(<15 \Omega . m)$, where the profile crosses Ribeiro Meirinho and near the well, is indicative of the presence of water with high ionic content. The region of higher resistivity in Algozl, located between the river and the well, coincides with the transition between the two topographic levels on site: one around the elevation of $60 \mathrm{~m}$, where the river flows, and another over the elevation of $70 \mathrm{~m}$-where the well is located - and behaves as a barrier to the movement of groundwater; this enhances the recovery of the hydrostatic level of the well after water extraction, as reported by the owner of a neighbouring house.

Site B-ERT profile Algoz3 (Figs. 5 and 9) presents a top layer of relative lower resistivity $(<2,240 \Omega$.m) when compared to the rest of the profile, which correlates with the joint presence of terrarossa (a clayey soil) and water with nitrates from orange tree irrigation. During the drilling of the water supply borehole, located in the vicinity of Algoz3, the log material was very heterogeneous (crushed rock) until $40 \mathrm{~m}$ depth and without water. This description fits

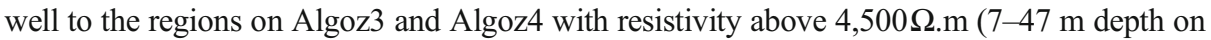
Algoz3 and at depth greater than $25 \mathrm{~m}$ on profile Algoz4 $(0-220 \mathrm{~m}))$. These zones are interpreted as resistive limestone. When well boring reached circa $70 \mathrm{~m}$ depth $(0 \mathrm{~m}$ a.s.1.), the water level rose to $50 \mathrm{~m}$. At about the same ground level (0 $\mathrm{m}$ a.s.1.), the resistivity drops to

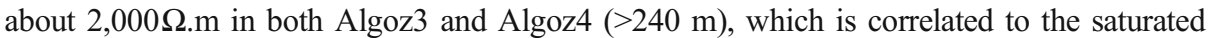
rock basement. Coincidentally, at this point of Algoz4, Ribeiro Meirinho inflects to the southwest, which could be due to the fact that the bedrock is far more compact in the north part of the profile until this point. Therefore, the south end of Algoz4 may well be an appropriate place for aquifer recharge. In this area, the water quality results do not show a 


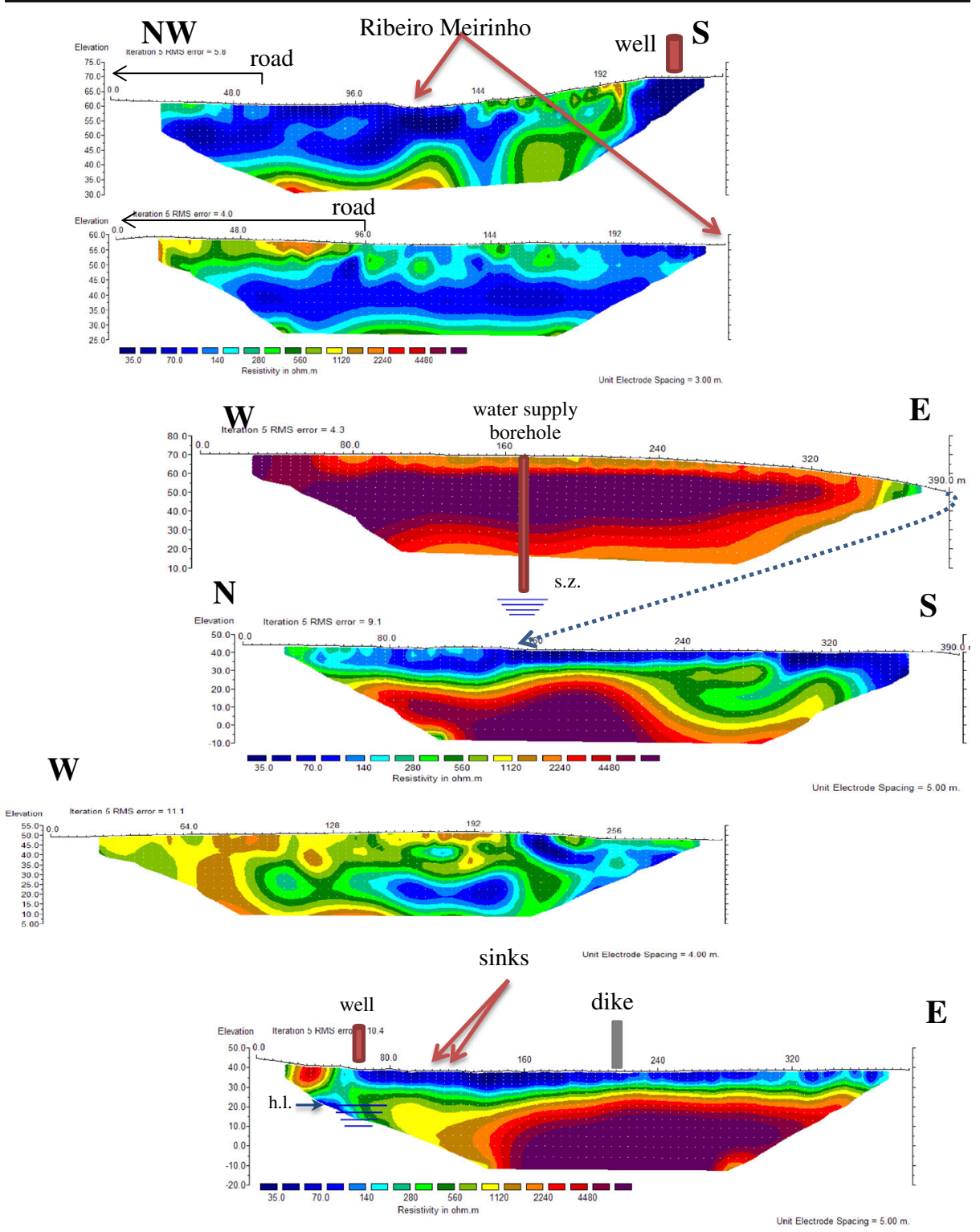

Fig. 9 Resistivity model profiles (upper-site A: Algoz1 (top) and Algoz2 (bottom); middle-site B: Algoz3 (top) and Algoz4 (bottom) (s.z.- top of saturated zone); bottom-site C: Algoz5 (top) and Algoz6 (bottom))

relationship between surface- and groundwater, possibly due to a thick non-saturated zone that the pollutants need to cross from the surface to the water table.

Site C-The resistivity model for ERT Algoz5 (Figs. 5 and 9) shows a high resistivity value closer to the well (presented in Algoz6 profile) at a higher topographic level. This leads to the conclusion that the topsoil at this location has a higher permeability than in the surrounding area, since water is being drained into the well, where the hydrostatic level (h.l.) is about $25 \mathrm{~m}$ deep. This means that the place is good for aquifer recharge, requiring its protection to prevent 
entry of polluted water into the aquifer. A dike was built for retaining river waters (see profile Algoz6), given the large amount of water that is drained by several sinks existing along its banks and bed, some of which were identified in the course of this survey, on the right bank, between the well and the dike. From Algoz6 stands out the thicker low resistivity top layer, located upstream of the dike, showing the highest infiltration capacity of the upstream area. This may also be due to the presence of the dike, which holds water that may have circulated in the stream during the previous week. Basement rock has resistivity values in the same order of magnitude as those from Site B, showing the same characteristics at both sites.

\section{Conclusions}

From water quality and geophysical surveys performed in the Querença-Silves case study, the main impacts of the existing stressors on the water quality pattern were identified, as well as the sites where surface- and groundwater are interconnected and favourable to both aquifer recharge and the entrance of pollutants into the aquifer (several areas of Algoz1, 2, 4, 5 and 6 profiles).

A general increase in resistivity of the top layers is observed from the upstream (site A) to the downstream (site B) profiles taken in Ribeiro Meirinho river bed (Algoz1, 2 and 4). Since the geologic environment is similar between sites $\mathrm{A}$ and $\mathrm{B}$, and the resistivity rises from $\mathrm{A}$ to $\mathrm{B}$, resistivity models confirm the chemical results whereas surface water quality is poorer, and therefore, have higher electrical conductivity in the north (site A) when compared to the south (site B). The WWTP plant was identified as the main reason for the degradation of the surface water quality of Ribeiro Meirinho, which in turn impacts the groundwater quality. On the other hand, agricultural practices have contributed with diffuse nitrate loads around six times higher than those from the WWTP. In the long term values, a seasonal effect (due to fertilization input) is clear in most wells. This confirms the high recharge rates of this aquifer, which allow for the input of cleaner water in periods of low fertilization, decreasing the nitrates concentrations, but also the effect of irrigation charged with excess of nitrates.

Finally, the combined analysis of geophysical and water quality surveys leads to the conclusion that in several profiles, the top soil acts like a filter, retaining the contaminants from the WWTP and agriculture activities (e.g., site B, Algoz3 profile).

Acknowledgments The work was financed by the Portuguese Foundation for Science and Technology under PROWATERMAN project PTDC/AAC-AMB/105061/2008 (http://www.lnec.pt/organizacao/dha/organizacao/ dha/nas/estudos_id/PROWATERMAN). We thank Águas do Algarve (AdA) and Agência Portuguesa do Ambiente (APA-ARH Algarve) for their support during this project, including the chemical analysis done in AdA. The help of Prof. Jeff Camkin, from the University of Western Australia, in reviewing and correcting the text is gratefully acknowledged. The authors are indebted to two anonymous reviewers for their useful suggestions to improve this paper. An initial version of this paper was presented at the 8th International Conference of the EWRA in Porto, Portugal, June 26-29, 2013.

\section{References}

Carriere SD, Chalikakis K, Senechal G, Danquigny C, Emblanch C (2013) Combining electrical resistivity tomography and ground penetrating radar to study geological structuring of karst unsaturated zone. J Appl Geophys. doi:10.1016/j.jappgeo.2013.03.014

Costa FE, Brites JA, Pedrosa MY, Silva AV (1985) Hydrogeological map of the Algarve region, Scale 1:100 000. Serviços Geológicos de Portugal, Lisboa, In Portuguese: Carta hidrogeológica da Orla Algarvia 
Gemail KS, El-Shishtawy AM, El-Alfy M, Ghoneim MF, Abd El-Bary MH (2011) Assessment of aquifer vulnerability to industrial waste water using resistivity measurements. A case study, along El-Gharbyia Main Drain, Nile Delta, Egypt. J Appl Geophys. doi:10.1016/j.jappgeo.2011.06.026

Isherwood KF (2000) Fertilizer use and the environment. International Fertilizer Industry Association, Paris

Loke MH (2002) RES2DINV, Ver. 3.50, Rapid 2-D resistivity \& IP inversion using the least-squares method. Geotomo Software, Penang

Loke MH, Barker RD (1996) Rapid least-squares inversion of apparent resistivity pseudosections using a quasiNewton method. Geophys Prospect 44:131152

Meju M (2002) Environmental geophysics: conceptual models, challenges, and the way forward. Lead Edge 21: 460-464

Mendonça L, Almeida C (2003) Exploitation of groundwater resources: the example of aquifer system QuerençaSilves. Recur Hídr J 24(3):53-61, In: e-geo.ineti.pt/edicoes_online/obras/costa_almeida/tp067.pdf. (in Portuguese: A Exploração de Recursos Hídricos Subterrâneos: O Exemplo do Sistema Aquífero Querença-Silves)

Monteiro JP, Guerreiro P, Martins J, Matos Silva J, Reis E (2006) Algibre Stream and the aquifers of Algarve Central: relationships between surface- and groundwater. Project POCI/AMB/57432/2004 Groundwater Flow Modelling and Optimisation of Groundwater Monitoring Networks at the Regional Scale in Coastal Aquifers: The Algarve Case-study. In:http:/www.cvrm.ualg.pt/projectos/malgar/publ_archive/7_rel-subsup-V0_ok.pdf. In Portuguese: A Ribeira do Algibre e os Aquíferos do Algarve Central: Relações entre Águas Superficiais e Subterrâneas

NEMUS, ECOSSISTEMA, AGRO.GES (2011) Watershed management plans integrated in hydrographic regions 6 and 7. Technical Report for Public Discussion, Lisbon. In Portuguese: Planos de gestão das bacias hidrográficas integradas nas regiões hidrográficas 6 e 7. Região Hidrográfica 6. Relatório técnico para efeitos de participação pública, pp 386

Nielsen DM (1991) Practical handbook of groundwater monitoring. Lewis Publishers, Chelsea, 717

Oliveira MM (2011) Conceptualization of recharge processes and water budgets of aquifer systems in watershed's water resources management framework. 8th Seminar on Groundwater, Lisbon. In Portuguese: Conceptualização do processo de recarga e do balanço hídrico de sistemas aquíferos no planeamento de recursos hídricos por sub-bacias hidrográficas

Oliveira MM, Oliveira LS (2012) Water, aquatic ecosystems and human activity project PROWATERMAN. 5th Thematic Report. Recharge and direct runoff assessment of Querença-Silves aquifer system catchment area. Repor 180/2012-NAS. LNEC, pp. 108. In Portuguese: Água, Ecossistemas Aquáticos e Atividade Humana Projeto PROWATERMAN. Quinto Relatório Temático - Estimativa da recarga e do escoamento direto na área de drenagem do sistema aquífero Querença-Silves

Oliveira MM, Oliveira L, Lobo Ferreira JP (2008) Evaluation of natural recharge of Querença-Silves aquifer system (Algarve). 9th Water Congress, Cascais, 15 pp. In Portuguese: Estimativa da Recarga Natural no Sistema Aquífero de Querença-Silves (Algarve) Pela Aplicação do Modelo BALSEQ_MOD

Reis E, Gago C, Borges G, Matos M, Cláudio A, Mendes E, Silva A, Serafim J, Rodrigues A, Correia S (2007) Contribution to water budget evaluation of the main aquifer systems of Algarve. Ministry of Environment and Regional Development. CCDR, pp 41. In Portuguese: Contribuição para o cálculo do balanço hídrico dos principais sistemas aquíferos do Algarve

Sainato CM, Losinno BN, Malleville HJ (2012) Assessment of contamination by intensive cattle activity through electrical resistivity tomography. J Appl Geophys 76:82-91

Yazicigil H, Sendlein LVA (1982) Surface geophysical techniques in groundwater monitoring - Part II, Groundwater Monitoring Revue, winter 2(1):56-62 